Role of agricultural engineering in environmental and sustainable development for the valley and delta areas: 1162- 1183

\title{
REVISING WETTED SOIL VOLUME UNDER TRICKLE SOURCE FOR IRRIGATION SCHEDULING
}

\author{
Kamal H. Amer ${ }^{a}$, Amal Elsharkawi ${ }^{\mathrm{b}}$, Ahmed S. Hassan ${ }^{\mathrm{b}}$
}

ABSTACT

Wetted soil shape under trickle irrigation is an important parameter in irrigation scheduling and design in agricultural farms. Irrigation water should not be beyond crop root zone to avoid deep percolation. Moreover, irrigation water applied should adequate crop water use in irrigation interval. The purpose of this work is to figure out the suitable shape of wetted soil based on soil type, flow rate, and crop water use. A field experiment was conducted in sand, silt and clay soils under trickle source with varying flow rates as 2, 4, 8, 16, and 24 liter/h. Squash, corn, and grape crops were selected to represent different root zones for irrigation scheduling. Field results showed that horizontal and vertical water movements were related to both emitter flow rate and soil intake rates. Suitable flow rate and irrigation interval were found for selected soil and crop types. Soil moisture content was contoured directly after irrigation and soil-water redistribution. Optimal flow rates were 2 and 4 liter/h in clay soil, 8 and 16 liter/h in loam, 16 and 24 liter/h in sand. Adjusted method was recommended to calculate irrigation interval by revising wetted root zone volume, taking into account different soil, crops, crop stages, and seasons.

Keywords: Wetted soil volume; Trickle irrigation; Irrigation scheduling.

\section{INTRODUCTION}

$\mathrm{M}$ ost of Egyptian croplands must be irrigated because rainfall is insufficient during the year-long growing season. Increased demands for water, and its high cost, necessitate efficient irrigation practice that is, practices that make the best possible use of irrigation water for crop production. Irrigation practice depends on the information among soil, weather, irrigation system, and crop that be used to schedule water by irrigation system. Precision irrigation requires a method of quantifying the root zone depletion of water to determine

\footnotetext{
${ }^{a}$ Dep. of Agr. Eng., Menofia University, Shibin El-Kom, Egypt,

${ }^{\mathrm{b}}$ Research Institute of Agr. Eng., Agriculture Ministry, Geza, Egypt.
} 
when and how much water to apply to the soil. Soil water deficit has been used to assess the need of irrigation (Bjerkholt and Myhr, 1996; Howell et al., 1997; Amer et al., 2009). The irrigation practices needed to give the most efficient use of water may vary widely within Egypt soils and locations. Soil properties are the responsible indicators to determine the amount of water that should be stored into crop root zone per irrigation, thus, irrigation interval. Therefore, water demands varies according to soil type from sandy to clay soils, amount per irrigation that the soil can be hold it, weather condition that crops growing in tropical area or dry seasons need more water than in semi-tropical and humid area or wet seasons.

Wetted soil volume geometry under trickle irrigation takes ellipsoidallike shape when water is applied from a point source (Zur, 1996). Wetted volume dimensions under a point source, its width and depth, depend on soil hydraulic properties, emitter flow rate, and water applied amount. Wetted soil volume is heterogeneous in water distribution and surrounded by drier soil. As, soil water content distribution within wetted volume is not uniform; it decreases with radial distance from the water source. Thus, wetted soil shape under a point source is representative of most practical situations in trickle irrigation design. One approach to estimate wetted soil volume under a given trickle system is to use analytical or numerical solutions of two- or three-dimensional unsaturated flow equations such as those presented by Brandt et al. (1971), Bresler (1978), and Fernandez and Simmonds (2006). These methods are capable of computing both the wetted soil depth and width, and thus the extent of the wetted volume under a range of soil, emitter flow rate and amount of water application. Emitter spacing can then be estimated, provided detailed information on soil hydraulic properties is available. However, these methods are of limited practical value because of their relative complexity, limited testing under field conditions, and lack of sufficient information on soils hydraulic properties in field.

A more widely used procedure to account wetted soil volume under trickle irrigation is to assume that wetted soil volume can be represented by the geometry of a rectangular column. The area of its base equals the product of the spacing between emitters and the distance between lines, 
while its height equals the depth of the root zone. Keller and Bliesner (1990) present a table where the spacing between emitters and between lines under an emitter with a flow rate of $41 \mathrm{~h}^{-1}$ are given for a number of soils, rooting depths and degrees of soil profile homogeneity. Similar tables have been presented by Schwartzman and Zur (1986) studied the geometry of wetted soil volume under trickle irrigation and developed a series of empirical equations relating the width and depth of the wetted soil volume to emitter flow rate, saturated hydraulic conductivity of the soil and volume of water applied. They computed empirical coefficients for these equations based on laboratory tests and on solutions of the twodimensional flow equation presented by Bresler (1978). Schwartzman and Zur (1986) have shown that the ratio of the width of the depth of the wetted soil volume would tend to decrease with an increase in the hydraulic conductivity of the soil. An increase in the depth of applied water would also decrease the width to-depth ratio; this is especially significant in light textured soils. In addition, an increase in emitter flow rate would increase the width-to-depth ratio with a more pronounced effect in medium-to-heavy textured soils. They proposed a procedure for selecting emitter spacing and emitter flow rate in order to obtain a desired geometry of the wetted soil volume. Amir and Dag (1993) published field data on the width and depth dimensions of wetted soil volumes under trickle source and reported good agreement with the empirical model presented by Schwartzman and Zur (1986). They stated that wetted soil volume can be controlled by emitter flow rate and spacing and amount of water applied. This fact creates an ideal situation for using an inverse approach to the design process. The inverse approach would start by estimating the magnitude of a desired wetted soil volume, then compute a number of possibilities of its width-depth relations and only then select possible combinations of emitter spacing and emitter flow rate to satisfy the possible width-depth combinations. The final step could then be the selection of an optimal combination of emitter flow rate and emitter spacing for the given field situation.

Previous studies on water infiltration into soils under a point-source dealt mainly with the soil moisture content or wetting front advance pattern during or just after the termination of the irrigation process (Brandt et al., 
1971; Ben- Asher et al., 1978; Schwartzman and Zur, 1986; Ben-Asher et al., 1993; Zur, 1996: Wu et al., 1999; Elmaloglou and Malamos; 2006). In contrast, a few studies dealt with the wetted pattern when soil moisture content redistributed around field capacity point as interrelated to irrigation scheduling (Fernandez and. Simmonds, 2006; Elmaloglou and Diamantopoulos, 2007).

The objectives of the present work are to define wetted soil volume under trickle irrigation directly after irrigation and redistribution and select appropriate flow rate based on soil type. One goal of the study is to determine irrigation duration and interval proposing different plant root zones.

\section{MATERIALS AND METHODS}

Field experimental work was conducted in Agriculture College, Menofia University, Egypt which clay soil was located. Sand and loam soils were previously moved from Behera Governerate to college farm at Shibin El Kom. The average values of particle size distribution, bulk density, and saturated hydraulic conductivity for the selected soil types are presented in Table 1. Soil infiltration was measured using double-ring infiltrometer. Saturated hydraulic conductivity was considered as final infiltration rate for each soil type.

The soil wetting patterns included maximum depth (z) and maximum width $(d)$, surface width $\left(d_{s}\right)$, and depth between maximum and surface widths (h) of wetted zone were observed for different emitter flow rates of $2,4,8,16$, and 24 liter/h after $6,3,1.5,0.75$, and $0.5 \mathrm{~h}$ operating duration of emitter, respectively. Moreover, 24 liter/h flow rate was studied for operating durations of $0.5,1$, and $1.5 \mathrm{~h}$ on sand soil. The wetting pattern was measured by digging soil pits across the wetted length on the surface. It was confirmed by tracking soil moisture content measurements. The horizontal and vertical wetting distances on wetted face of pit were recorded in a grid form for each emitter flow rate and operating duration of emitter. 
Table 1: Physical properties of soil types, bulk density, and conductivity.

\begin{tabular}{|c|c|c|c|c|c|c|c|c|}
\hline \multirow{2}{*}{$\begin{array}{c}\text { Soil } \\
\text { type }\end{array}$} & \multicolumn{3}{|c|}{$\begin{array}{c}\text { Particles size distribution } \\
(\%)\end{array}$} & \multicolumn{2}{|c|}{$\begin{array}{c}\text { Volumetric water content at } \\
(\%)^{*}\end{array}$} & $\begin{array}{c}\text { Bulk } \\
\text { density }\end{array}$ & $\mathrm{k}_{\mathrm{s}}$ \\
\cline { 2 - 10 } & Sand & Silt & Clay & PWP & FC & SP & $\mathrm{g} \mathrm{m}^{-3}$ & $\mathrm{~mm} \mathrm{~h}^{-1}$ \\
\hline Sand & 86.7 & 7.8 & 5.5 & 3.6 & 11.8 & 26.4 & 1.57 & 252 \\
\hline Loam & 61.3 & 23.1 & 15.6 & 10.4 & 21.8 & 34.6 & 1.42 & 126 \\
\hline Clay & 17.79 & 31.14 & 51.07 & 21.5 & 42.3 & 65.7 & 1.28 & 32 \\
\hline
\end{tabular}

"PWP, permanent wilting point; FC, field capacity; SP, saturation point; $\mathrm{k}_{\mathrm{s}}$, saturated hydraulic conductivity.

Since soil moisture dielectric sensors could be affected by soil texture, bulk density and the soil properties, also measurements require an in situ calibration because they are in the sphere of the influence of the dielectric sensor; soil samples were taken by delicate auger each $10 \mathrm{~cm}$ of horizontal and vertical distances in soil wetting volume. Soil moisture content measurements before irrigation, just after irrigation, and after soil-water redistribution were radially measured around selected emitters. Soil surface just after irrigation was covered with plastic sheets to be protected from evaporation until taking samples after irrigation redistribution (24 h).

Squash, corn, and grape crops were selected to express three different irrigation schedule depths as $0.6,1.0$, and $2.0 \mathrm{~m}$ for each soil type and full vegetative growth, respectively. Irrigation duration and interval were determined based on wetted soil depth after irrigation redistribution which was not greater than the root zone depth. Projected area as recommended was $0.5 \times 0.5 \mathrm{~m}$ for squash, $0.25 \times 0.6 \mathrm{~m}$ for corn, and $2 \times 2.5$ $\mathrm{m}$ for grape. In summer season, a $6 \mathrm{~mm}$ of peak daily crop water use for the selecting crops was regionally recommended according to Amer (2010). For a given plant root zone, an emitter was used for each squash plant and for two corn plants. Emitters were installed $0.5 \mathrm{~m}$ along lateral for squash and corn crops. For given emitter flow rate and full-vegetative of grape tree, four emitters where each emitter set $0.2 \mathrm{~m}$ apart from the grape tree on perpendicular directions were projected for each grape tree. For a given projected crop area, peak daily crop water use (PET) was 
determined as 1.5, 0.9, and 30 liter/day for each squash plant, corn plant, and grape tree, respectively.

The volume of the wetted soil under a point source could be described as a vertical truncated ellipsoid with horizontal circular area directly after irrigation, Fig. 1. The volume $\left(\mathrm{V}\right.$ in $\left.\mathrm{m}^{3}\right)$ of a truncated ellipsoid was developed in this work using integration methods as follows:

$$
V_{S}=\frac{\pi}{6} z d^{2}+\frac{\pi}{12} h d_{s}^{2}
$$

where $\mathrm{d}$ is the maximal width occurring at a depth $\mathrm{h}$ below the soil surface $(m), d_{s}$ is the width occurring at the soil surface $(m)$, and $z$ is the vertical extent of this volume $(\mathrm{m})$.

Equations 2 and 3 express the relationship of wetted soil depth and width to emitter flow rates directly after irrigation (Schwartzman and Zur 1986) as follows:

$$
\begin{gathered}
z=2.54 V_{w}^{0.63}\left(\frac{k_{s}}{q}\right)^{0.45} \\
d=1.32 z^{0.35}\left(\frac{q}{k_{s}}\right)^{0.33}
\end{gathered}
$$

where $\mathrm{V}_{\mathrm{w}}$ is volume of water applied to the soil $\left(\mathrm{m}^{3}\right), \mathrm{k}_{\mathrm{s}}$ is saturated hydraulic conductivity of the soil $\left(\mathrm{m} \mathrm{s}^{-1}\right)$, and $\mathrm{q}$ is point source flow rate $\left(\mathrm{m}^{3} \mathrm{~s}^{-1}\right)$.

After soil-water redistribution, wetted soil volume was vertically extended by $\ell$ length due to gravitational effect; but, it was insignificantly changed in horizontal directions as shown in Fig. 1. Therefore, the length $\ell$ was developed in this work in the following equation:

$$
\ell=z \frac{\theta_{f}-\theta_{f c}}{\theta_{f_{c}}-\theta_{i}}
$$

where, $\theta_{\mathrm{f}}, \theta_{\mathrm{fc}}$, and $\theta_{\mathrm{i}}$ are, respectively, volumetric soil moisture content just after irrigation, at field capacity, and before irrigation.

Irrigation duration ( $\mathrm{t}$ ) was derived by setting $\mathrm{V}_{\mathrm{w}}=\mathrm{q}$ t in Eq. 2; therefore, $\mathrm{t}$ in second was found as a function of $\mathrm{z}, \mathrm{q}$, and $\mathrm{k}_{\mathrm{s}}$ as follows:

$$
t=0.22 z^{1.59} q^{-0.29} k_{s}^{-0.72}
$$


Irrigation interval (I in day) that should be applied was determined as follows:

$$
I=\frac{n q t}{K_{c} E T}
$$

where ET is crop water use (liter/day), $\mathrm{K}_{\mathrm{c}}$ is crop coefficient which equals unity in full vegetative growing stage, and $\mathrm{n}$ is emitters number. Wetted soil depth after soil-water redistribution $(\mathrm{z}+\ell)$ should not exceed more than crop root zone depth. Therefore, $\mathrm{z}$ and $\ell$ should be managed from Eq. (4) and crop root zone. Because irrigation interval should be integral number, adjusted irrigation operating time $\left(\mathrm{t}_{\mathrm{i}}\right)$ was determined to match the integrity of interval and number of emitters per plant.

Fig. 1. Schematic of

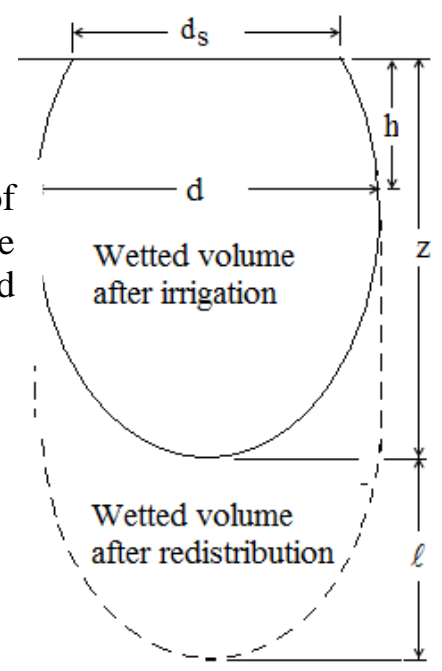

Linear regression was used to test the agreement between two variables, $\mathrm{x}$ and $\mathrm{y}$. Here, the regression was analyzed where the best fitting line was forced through the origin (zero intercept, $\mathrm{y}=\mathrm{b} \mathrm{x}$ ) and getting their original coefficient of determination $\left(r^{2}\right)$. According to Singh et al. (2006), coefficient of efficiency (E) which shows the closeness between two variables $\mathrm{y}$ and $\mathrm{x}$ was determined as follows:

$$
E=1-\frac{\sum_{i=1}^{n}[y-x]^{2}}{\sum_{i=1}^{n}[x-\bar{x}]^{2}}
$$


where $\mathrm{x}$ and $\mathrm{y}$ are the observed and predicted values, respectively, and $\bar{x}$ is the mean of measured values.

According to Singh et al. (2006), root mean square error (RMSE) was estimated as follows:

$$
R M S E=\sqrt{\frac{\sum_{i=1}^{n}[y-x]^{2}}{n}}
$$

where $\mathrm{n}$ is the number of observations.

\section{RESULTS AND DISCUSSION}

Wetted soil patterns as influenced by different emitter flow rates (q) with constant amount of water applied (12 liter) were experimentally found in clay soil as presented in Fig. 2. Consequently, operating emitter time (t) was $6,3,1.5,0.75$, and $0.5 \mathrm{~h}$ for $2,4,8,16$, and $241 / \mathrm{h}$ emitter flow rate, respectively. Surface wetted soil width $\left(\mathrm{d}_{\mathrm{s}}\right)$ was $0.33,0.41,0.50,0.54$, and $0.64 \mathrm{~m}$, respectively. Maximum wetted soil width (d) was $0.42,0.48$, $0.54,0.60$, and $0.67 \mathrm{~m}$, respectively. Wetted soil depth (z) was 0.52, 0.40, $0.32,0.24$, and $0.21 \mathrm{~m}$, respectively. For given water applied amount, results showed that irrigation duration and wetted soil depth values significantly increased as emitter flow rate decreased; nevertheless, $d_{s}$ and $d$ decreased. These results were also presented in Table 2 for clay soil. Initial soil moisture contents of $0.318 \mathrm{~m}^{3} \mathrm{~m}^{-3}$ was found in the beginning of the irrigation for all considered clay sites. At the end of the irrigation, final moisture contents were measured as 0.516, 0.529, 0.537, 0.551 , and 0.594 under $2,4,8,16$, and 24 liter/h emitter flow rate, respectively. It seemed that the higher the flow rate of emitter the higher the final moisture content in soil. These results obtained because soil water transient from quickly drainable pores under low flow rate was higher than that under high flow rate of emitter. Moreover, irrigation duration $(t)$ was also higher for low flow rate of emitter compared with that of high flow rate in which all had the same amount of water applied; therefore, some water leaching from the upper soil surface during irrigation duration. 


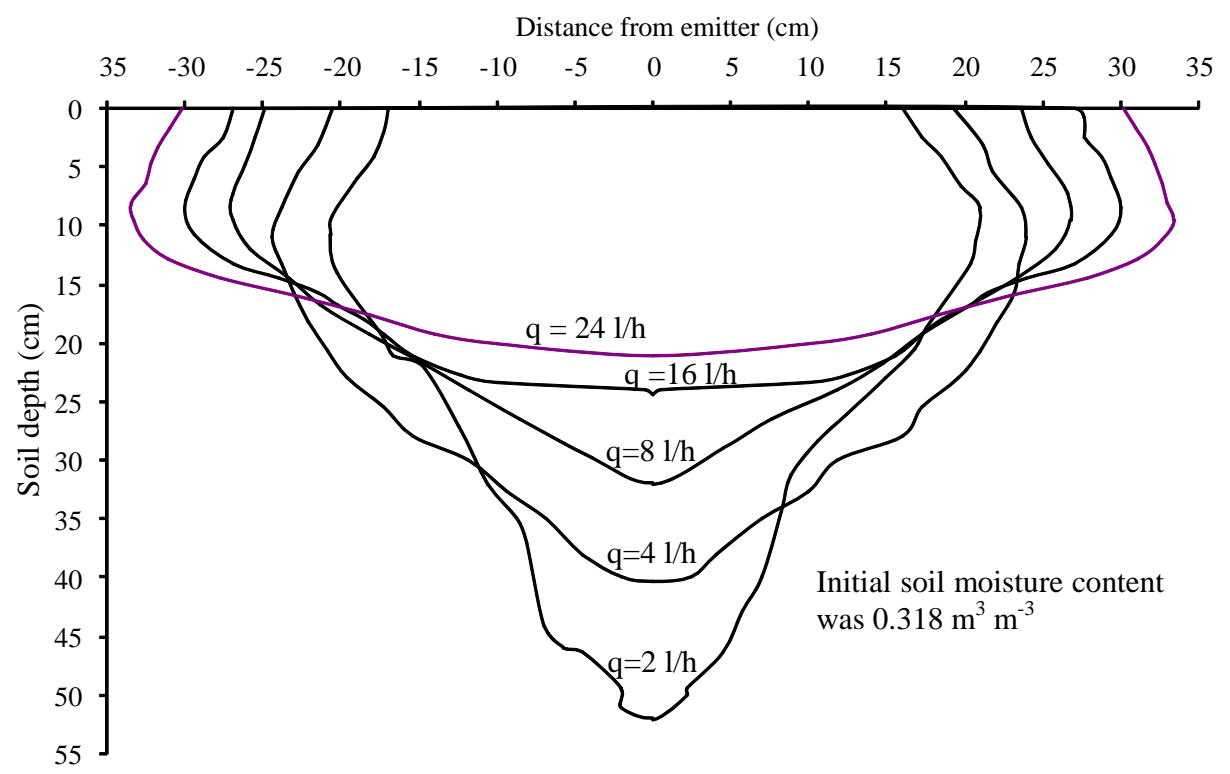

Fig. 2. Wetting patterns front under different emitter flow rates with 12 liter water amount in clay soil.

Wetted soil patterns front as influenced by different soil types under 8 liter/h flow rate of emitter with $1.5 \mathrm{~h}$ operating time were presented in Fig. 3. Surface wetted soil width $\left(\mathrm{d}_{\mathrm{s}}\right)$ was $0.49,0.44$, and $0.36 \mathrm{~m}$ for clay, loam, and sand soils, respectively. Maximum wetted soil width (d) was $0.54,0.49$, and $0.42 \mathrm{~m}$, respectively. Wetted soil depth (z) was $0.32,0.54$, and $0.75 \mathrm{~m}$, respectively. For given flow rate of emitter and water applied volume, results showed that $\mathrm{z}$ values significantly increased as soil infiltration increased; but, $d_{s}$ and $d$ decreased. Field saturated hydraulic conductivity $\left(\mathrm{k}_{\mathrm{s}}\right)$ was found using infiltrometer as 32,126, and $252 \mathrm{~mm}$ $\mathrm{h}^{-1}$ for clay, loam, and sand soils, respectively. Using 8 liter/h flow rate with $1.5 \mathrm{~h}$ operating time of emitter, water transient was fast achieved with soil that had light texture and high final infiltration rate. Initial soil moisture content was $0.318,0.142$, and $0.05 \mathrm{~m}^{3} \mathrm{~m}^{-3}$ for clay, loam, and sand soils, respectively, as presented in Table 2. But, final soil moisture content was $0.537,0.323$, and $0.222 \mathrm{~m}^{3} \mathrm{~m}^{-3}$, respectively. 


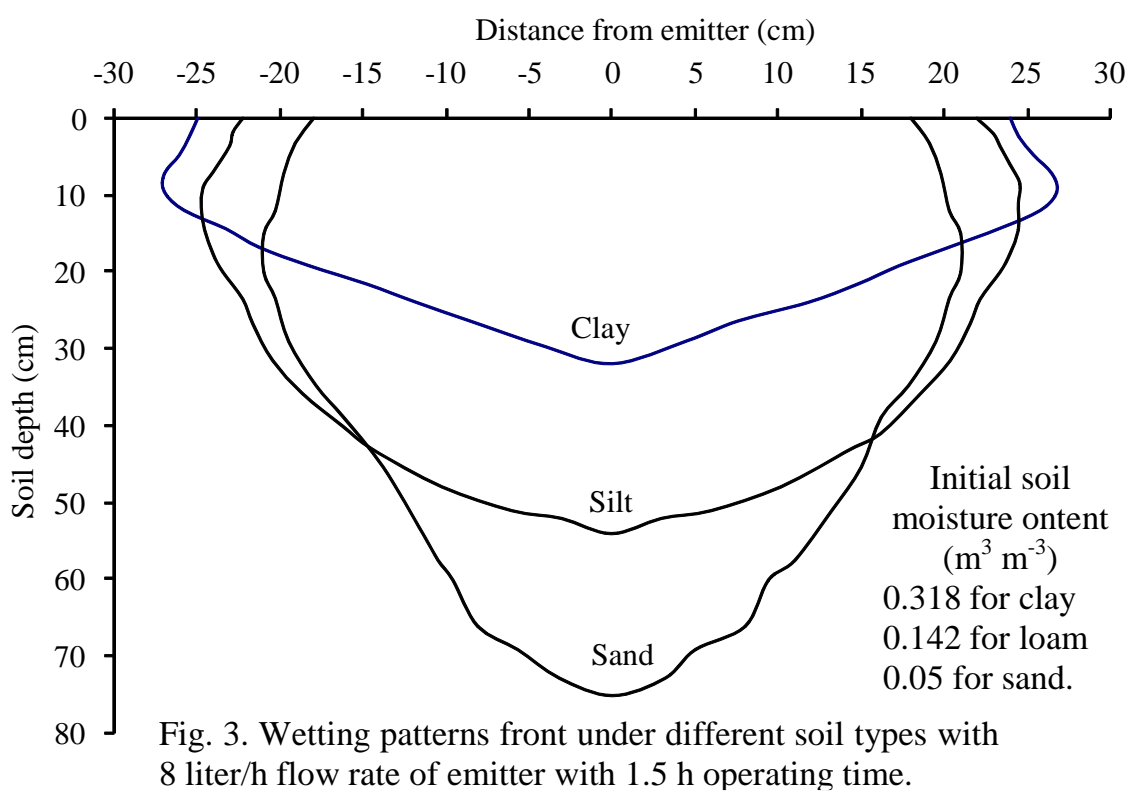

Wetted soil patterns front as affected by different operating durations of emitter under 24 liter/h flow rate in sand soil were presented in Fig. 4. Emitter operating duration ( $\mathrm{t}$ ) of $0.5,1.0$, and $1.5 \mathrm{~h}$ achieved $0.50,0.53$, and $0.60 \mathrm{~m}$ maximum wetted soil width (d) and 0.50, 0.70, and $0.90 \mathrm{~m}$ wetted soil depth (z), respectively. For given emitter flow rate and sand soil type, results showed that wetted soil width and depth were increased as operating time of emitter increased, suggesting that rising water volume applied needed to store in larger wetted soil volume.

The individual effects of different emitter flow rates and soil types on wetted soil widths, depths, and moisture contents after irrigation and its redistribution were presented in Table 2. By applying 12 liter water volume, operating duration of emitter (t) as well as vertical water movements ( $\mathrm{z}, \mathrm{z}+\ell$, and $\mathrm{h}$ ) increased as flow rate of emitter (q) decreased. However, horizontal water movements $\left(d_{s}\right.$ and $\left.d\right)$ decreased as $\mathrm{q}$ decreased. Initial soil moisture content was $0.318,0.142$, and $0.05 \mathrm{~m}^{3}$ $\mathrm{m}^{-3}$ for clay, loam, and sand soils, respectively. Final soil moisture content after irrigation increased from 0.516 to $0.594 \mathrm{~m}^{3} \mathrm{~m}^{-3}$ in clay soil, from 0.294 to $0.338 \mathrm{~m}^{3} \mathrm{~m}^{-3}$ in loam soil, and from 0.195 to $0.238 \mathrm{~m}^{3} \mathrm{~m}^{-3}$ in sand soil as q increased from 2 to 24 liter/h, respectively. Nevertheless, final soil moisture content after soil-water redistribution was 
insignificantly changed in all soil types and reserved around field capacity point for each soil type as shown in Table 2 . Final soil moisture contents after irrigation and soil-water redistribution for each emitter flow rate were used to figure out hereafter irrigation duration and interval. For a given flow rate of emitter, results in Table 2 showed that horizontal water movements were greater in clay soil followed by loam, and then sand; however, vertical water movements were greater in sand soil which had the higher water intake compared with loam and clay soils.

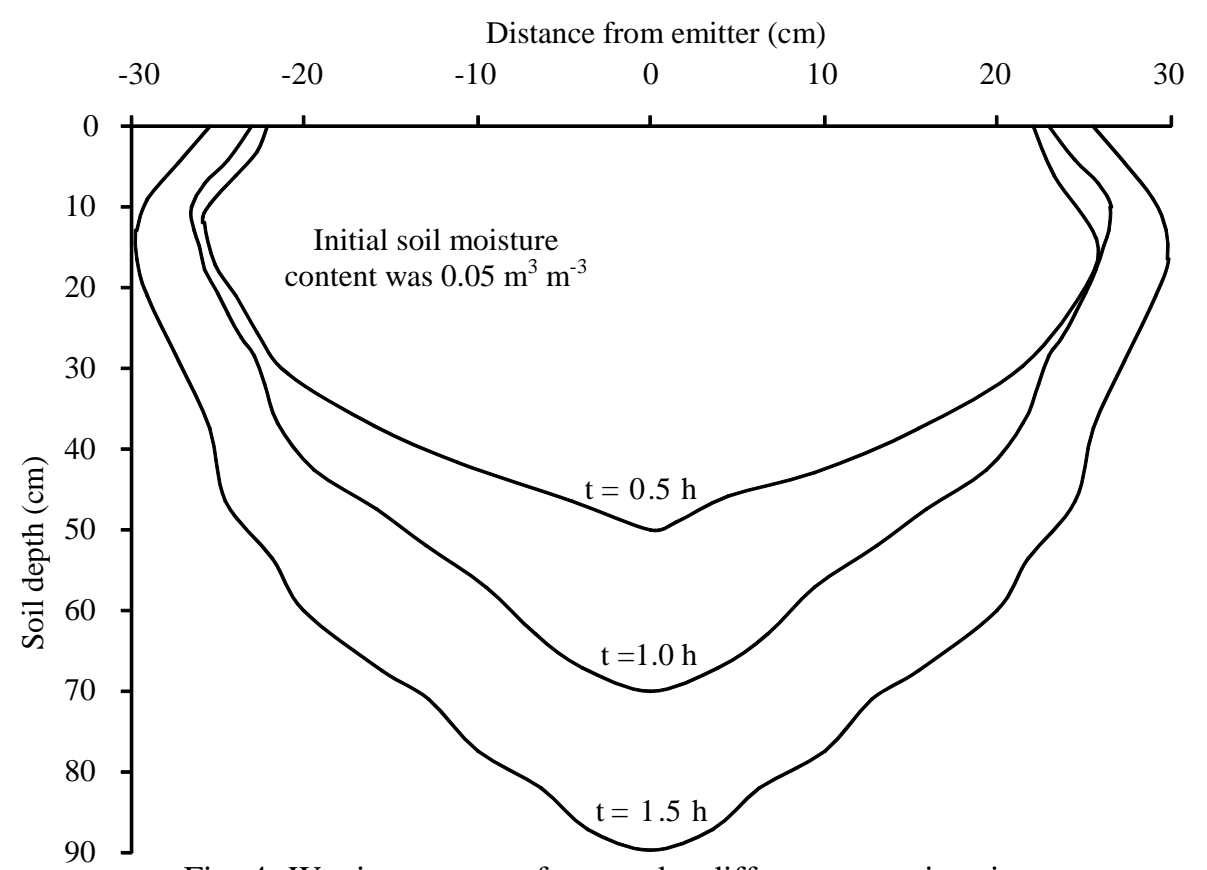

Fig. 4. Wetting patterns front under different operating times of emitter with 24 liter/h flow rate of emitter in sand soil.

The predicted values of wetted depth and width which represented y values (obtained from Eqs. 2, 3, and 4) were compared with those obtained through field experiments in which represented $\mathrm{x}$ values (Table 2) conducted under clay, loam, and sand soils. Linear regression equations were found as $\mathrm{y}=1.044 \mathrm{x}$ with $\mathrm{r}^{2}=0.98$ and $\mathrm{y}=0.978 \mathrm{x}$ with $r^{2}=0.97$ for wetted soil width and depth after irrigation, respectively. It was $y=0.962 x$ with $r^{2}=0.95$ for wetted depth $(z+\ell)$ after soil-water redistribution. Statistical analysis revealed that there was no significant 
difference between predicted (y) and observed (x) values of wetted soil width and depth. The effect of flow rate, soil type and duration of water application on wetted width and depth were almost similar for predicted and observed values. Predictability of model was expressed in terms of model efficiency (E) which was 0.97 and 0.943 with root mean square error (RMSE) as 0.05 and $0.02 \mathrm{~m}$, respectively, for prediction of wetted width and depth, respectively. Predictions of the wetted soil extended depth $(\ell)$ after soil-water redistribution calculated with Eq. (4) were found to be in good agreement with the observed data. E and RMSE were, respectively, found as $98 \%$ and $0.73 \mathrm{~m}$ for predicting extended wetted soil depth after soil-water redistribution $(\ell)$.

Table 2. Measured parameters after irrigation and soil-water redistribution for 12 liter water volume.

\begin{tabular}{|c|c|c|c|c|c|c|c|c|c|c|}
\hline \multirow{2}{*}{$\begin{array}{l}\text { Soil } \\
\text { type }\end{array}$} & \multirow{2}{*}{$\begin{array}{c}\theta_{\mathrm{i}} \\
\left(\mathrm{m}^{3} \mathrm{~m}^{-3}\right)\end{array}$} & \multirow{2}{*}{$\begin{array}{c}q \\
(1 / h)\end{array}$} & \multirow{2}{*}{$\begin{array}{c}\mathrm{t} \\
(\mathrm{h})\end{array}$} & \multirow{2}{*}{$\begin{array}{l}\mathrm{d}_{\mathrm{s}} \\
(\mathrm{m})\end{array}$} & \multirow{2}{*}{$\begin{array}{c}\mathrm{d} \\
(\mathrm{m})\end{array}$} & \multirow{2}{*}{$\begin{array}{c}\mathrm{h} \\
(\mathrm{m})\end{array}$} & \multicolumn{2}{|c|}{$\begin{array}{c}\text { Wetted } \\
\text { depths (m) }\end{array}$} & \multicolumn{2}{|c|}{$\begin{array}{c}\text { Final soil moisture } \\
\text { content after } \\
\left(\mathrm{m}^{3} \mathrm{~m}^{-3}\right)\end{array}$} \\
\hline & & & & & & & $\mathrm{z}$ & $\mathrm{z}+\ell$ & IR & IRR \\
\hline \multirow{5}{*}{ Clay } & \multirow{5}{*}{0.318} & 2 & 6 & 0.37 & 0.44 & 0.19 & 0.55 & 0.90 & 0.516 & 0.427 \\
\hline & & 4 & 3 & 0.45 & 0.5 & 0.12 & 0.4 & 0.75 & 0.529 & 0.429 \\
\hline & & 8 & 1.5 & 0.52 & 0.56 & 0.08 & 0.31 & 0.60 & 0.537 & 0.431 \\
\hline & & 16 & 0.75 & 0.59 & 0.64 & 0.06 & 0.22 & 0.50 & 0.551 & 0.432 \\
\hline & & 24 & 0.5 & 0.6 & 0.65 & 0.05 & 0.18 & 0.45 & 0.594 & 0.432 \\
\hline \multirow{5}{*}{ Loam } & \multirow{5}{*}{0.142} & 2 & 6 & 0.33 & 0.35 & 0.27 & 1.1 & 1.80 & 0.295 & 0.214 \\
\hline & & 4 & 3 & 0.36 & 0.4 & 0.22 & 0.75 & 1.50 & 0.313 & 0.217 \\
\hline & & 8 & 1.5 & 0.41 & 0.45 & 0.16 & 0.55 & 1.30 & 0.323 & 0.217 \\
\hline & & 16 & 0.75 & 0.46 & 0.5 & 0.11 & 0.45 & 1.00 & 0.327 & 0.218 \\
\hline & & 24 & 0.5 & 0.52 & 0.55 & 0.09 & 0.35 & 0.90 & 0.338 & 0.218 \\
\hline \multirow{5}{*}{ Sand } & \multirow{5}{*}{0.05} & 2 & 6 & 0.3 & 0.32 & 0.32 & 1.4 & $>2$ & 0.195 & 0.114 \\
\hline & & 4 & 3 & 0.32 & 0.35 & 0.28 & 1.0 & $>2$ & 0.218 & 0.116 \\
\hline & & 8 & 1.5 & 0.37 & 0.4 & 0.2 & 0.75 & $>2$ & 0.222 & 0.118 \\
\hline & & 16 & 0.75 & 0.42 & 0.45 & 0.15 & 0.56 & 1.53 & 0.232 & 0.118 \\
\hline & & 24 & 0.5 & 0.45 & 0.5 & 0.11 & 0.5 & 1.28 & 0.238 & 0.12 \\
\hline
\end{tabular}

${ }^{\dagger} \mathrm{q}$ is emitter flow rate, $\mathrm{t}$ is operating time, $\mathrm{d}_{\mathrm{s}}$ is surface wetted width, $\mathrm{d}$ is maximum wetted width occurring at a depth $\mathrm{h}$ below the soil surface, $\mathrm{z}$ and $(\mathrm{z}+\ell)$ are wetted soil depths after irrigation (IR) and after soil-water redistribution (IRR), respectively.

Irrigation scheduling parameters determined for squash, corn, and grape were presented in Table 3. For a given soil type, root zone $(\mathrm{z}+\ell)$ as a constraint parameter for squash, corn, and grape was $0.6,1.0$, and $2.0 \mathrm{~m}$, respectively. By using Eq. 4, extended wetted soil depth ( $\ell$ after IRR) 
after soil-water redistribution was firstly determined. Secondly, wetted soil depth (z) after irrigation was determined by subtracting the extended length $(\ell)$ from crop root zone depth $(\mathrm{z}+\ell)$. Therefore, irrigation duration ( $\mathrm{t}$ in Eq. 5) as well as irrigation interval (I in Eq. 6) was determined based on each soil type and crop. For a given soil type, irrigation interval increased as crop root zone increased. Results concluded that the greater the root zone the greater the stored water. Therefore, irrigation duration increased as root zone increased. For given root zone and emitter flow rate, irrigation interval firstly increased with high storage capacity of soil which was clay followed by loam, and then sand. For a clay soil, emitters with 2 and 4 liter/h were recommended because they achieved 3.90 and $5.81 \mathrm{~d}$ irrigation interval for squash, 7.33 and $10.85 \mathrm{~d}$ for corn, and 5.30 and $7.84 \mathrm{~d}$ for grape, respectively. For a loam soil, emitters with 8 and 16 liter/h which achieved 1.97 and $3.11 \mathrm{~d}$ irrigation interval for squash, 3.70 and $5.81 \mathrm{~d}$ for corn, and 2.68 and $4.24 \mathrm{~d}$ for grape, respectively, were recommended.

Table 3. Developed wetted soil depth, operating time of emitter, and irrigation interval based on squash, corn, and grape root zones in three different soil types. ${ }^{\dagger}$

\begin{tabular}{|c|c|c|c|c|c|c|c|c|c|c|}
\hline \multirow{2}{*}{$\begin{array}{c}\text { Crop root } \\
\text { zone } \\
(\mathrm{z}+\ell)\end{array}$} & \multirow{2}{*}{$\begin{array}{l}\text { Flow } \\
\text { rate } \\
(1 / h) \\
\end{array}$} & \multicolumn{3}{|c|}{ Clay soil } & \multicolumn{3}{|c|}{ Loam soil } & \multicolumn{3}{|c|}{ Sand soil } \\
\hline & & $\begin{array}{c}\mathrm{z} \\
(\mathrm{m})\end{array}$ & $\begin{array}{c}\mathrm{t} \\
(\mathrm{h})\end{array}$ & $\begin{array}{c}\text { I } \\
\text { (d) }\end{array}$ & $\begin{array}{c}\mathrm{z} \\
(\mathrm{m})\end{array}$ & $\begin{array}{c}\mathrm{t} \\
(\mathrm{h})\end{array}$ & $\begin{array}{c}\text { I } \\
\text { (d) }\end{array}$ & $\begin{array}{c}\mathrm{Z} \\
(\mathrm{m})\end{array}$ & $\begin{array}{c}\mathrm{t} \\
\text { (h) }\end{array}$ & $\begin{array}{c}\text { I } \\
\text { (d) }\end{array}$ \\
\hline \multirow{5}{*}{$\begin{array}{l}\text { Squash } \\
(0.6 \mathrm{~m})\end{array}$} & 2 & 0.35 & 2.93 & 3.90 & 0.27 & 0.72 & 0.96 & 0.25 & 0.40 & 0.53 \\
\hline & 4 & 0.33 & 2.18 & 5.81 & 0.24 & 0.50 & 1.34 & 0.22 & 0.26 & 0.68 \\
\hline & 8 & 0.31 & 1.65 & 8.81 & 0.23 & 0.37 & 1.97 & 0.21 & 0.20 & 1.07 \\
\hline & 16 & 0.30 & 1.25 & 13.32 & 0.22 & 0.29 & 3.11 & 0.20 & 0.15 & 1.59 \\
\hline & 24 & 0.25 & 0.83 & 13.31 & 0.21 & 0.24 & 3.77 & 0.19 & 0.12 & 2.00 \\
\hline \multirow{5}{*}{$\begin{array}{l}\text { Corn } \\
(1.0 \mathrm{~m})\end{array}$} & 2 & 0.58 & 6.60 & 7.33 & 0.45 & 1.64 & 1.82 & 0.42 & 0.89 & 0.99 \\
\hline & 4 & 0.54 & 4.88 & 10.85 & 0.40 & 1.12 & 2.48 & 0.36 & 0.57 & 1.27 \\
\hline & 8 & 0.52 & 3.76 & 16.71 & 0.38 & 0.83 & 3.70 & 0.35 & 0.45 & 2.02 \\
\hline & 16 & 0.49 & 2.80 & 24.88 & 0.37 & 0.65 & 5.81 & 0.33 & 0.34 & 3.00 \\
\hline & 24 & 0.42 & 1.91 & 25.47 & 0.35 & 0.53 & 7.08 & 0.30 & 0.26 & 3.44 \\
\hline \multirow{5}{*}{$\begin{array}{c}\text { Grape } \\
(2.0 \mathrm{~m})\end{array}$} & 2 & 1.15 & 19.86 & 5.30 & 0.89 & 4.92 & 1.31 & 0.83 & 2.66 & 0.71 \\
\hline & 4 & 1.08 & 14.70 & 7.84 & 0.80 & 3.37 & 1.80 & 0.72 & 1.73 & 0.92 \\
\hline & 8 & 1.04 & 11.32 & 12.08 & 0.75 & 2.51 & 2.68 & 0.70 & 1.35 & 1.44 \\
\hline & 16 & 0.98 & 8.42 & 17.97 & 0.74 & 1.99 & 4.24 & 0.66 & 1.02 & 2.17 \\
\hline & 24 & 0.83 & 5.70 & 18.23 & 0.70 & 1.62 & 5.17 & 0.64 & 0.86 & 2.74 \\
\hline
\end{tabular}

${ }^{\dagger} \mathrm{z}$ is wetted soil depth, $\mathrm{t}$ is operating time of emitter, and $\mathrm{I}$ is irrigation interval. 
Table 4. Revised wetted soil depths and operating time of emitter based on the integral irrigation interval in three different soil types.

\begin{tabular}{|c|c|c|c|c|c|c|c|c|c|c|c|c|c|}
\hline \multirow[b]{2}{*}{ Crop } & \multirow{2}{*}{$\begin{array}{c}\text { Flow } \\
\text { rate } \\
(1 / h)\end{array}$} & \multicolumn{4}{|c|}{ Clay soil } & \multicolumn{4}{|c|}{ Loam soil } & \multicolumn{4}{|c|}{ Sand soil } \\
\hline & & $\begin{array}{c}\mathrm{z} \\
(\mathrm{m}) \\
\end{array}$ & $\begin{array}{l}\mathrm{z}+\ell \\
(\mathrm{m})\end{array}$ & $\begin{array}{c}\mathrm{t}_{\mathrm{i}} \\
(\mathrm{h})\end{array}$ & $\begin{array}{c}\text { I } \\
\text { (d) }\end{array}$ & $\begin{array}{c}\mathrm{z} \\
(\mathrm{m}) \\
\end{array}$ & $\begin{array}{l}\mathrm{z}+\ell \\
(\mathrm{m})\end{array}$ & $\begin{array}{c}\mathrm{t}_{\mathrm{i}} \\
(\mathrm{h})\end{array}$ & $\begin{array}{c}\text { I } \\
\text { (d) }\end{array}$ & $\begin{array}{c}\mathrm{z} \\
(\mathrm{m}) \\
\end{array}$ & $\begin{array}{l}\mathrm{z}+\ell \\
(\mathrm{m})\end{array}$ & $\begin{array}{c}\mathrm{t}_{\mathrm{i}} \\
(\mathrm{h})\end{array}$ & $\begin{array}{c}\text { I } \\
\text { (d) }\end{array}$ \\
\hline \multirow{5}{*}{ Squash } & 2 & 0.29 & 0.51 & 2.25 & 3 & -- & -- & -- & -- & -- & -- & -- & -- \\
\hline & 4 & 0.30 & 0.55 & 1.88 & 5 & 0.20 & 0.50 & 0.38 & 1 & -- & -- & -- & -- \\
\hline & 8 & 0.29 & 0.56 & 1.50 & 8 & 0.23 & 0.60 & 0.38 & 2 & 0.20 & 0.57 & 0.19 & 1 \\
\hline & 16 & 0.29 & 0.59 & 1.22 & 13 & 0.21 & 0.58 & 0.28 & 3 & 0.15 & 0.44 & 0.09 & 1 \\
\hline & 24 & 0.24 & 0.59 & 0.81 & 13 & 0.18 & 0.51 & 0.19 & 3 & 0.19 & 0.59 & 0.13 & 2 \\
\hline \multirow{5}{*}{ Corn } & 2 & 0.56 & 0.98 & 6.30 & 7 & 0.31 & 0.69 & 0.90 & 1 & 0.42 & 1.01 & 0.90 & 1 \\
\hline & 4 & 0.52 & 0.95 & 4.50 & 10 & 0.35 & 0.87 & 0.90 & 2 & 0.31 & 0.86 & 0.45 & 1 \\
\hline & 8 & 0.51 & 0.97 & 3.60 & 16 & 0.33 & 0.87 & 0.68 & 3 & 0.35 & 0.99 & 0.45 & 2 \\
\hline & 16 & 0.48 & 0.98 & 2.70 & 24 & 0.33 & 0.90 & 0.56 & 5 & 0.33 & 0.99 & 0.34 & 3 \\
\hline & 24 & 0.41 & 0.99 & 1.88 & 25 & 0.34 & 0.98 & 0.53 & 7 & 0.27 & 0.85 & 0.23 & 3 \\
\hline \multirow{5}{*}{ Grape } & 2 & 1.12 & 1.94 & 18.75 & 5 & 0.75 & 1.69 & 3.75 & 1 & -- & -- & -- & -- \\
\hline & 4 & 1.01 & 1.87 & 13.13 & 7 & 0.55 & 1.38 & 1.88 & 1 & -- & -- & -- & -- \\
\hline & 8 & 1.04 & 2.00 & 11.25 & 12 & 0.62 & 1.66 & 1.88 & 2 & 0.55 & 1.58 & 0.94 & 1 \\
\hline & 16 & 0.95 & 1.94 & 7.97 & 17 & 0.71 & 1.92 & 1.88 & 4 & 0.62 & 1.89 & 0.94 & 2 \\
\hline & 24 & 0.82 & 1.98 & 5.63 & 18 & 0.68 & 1.95 & 1.56 & 5 & 0.52 & 1.63 & 0.63 & 2 \\
\hline
\end{tabular}

${ }^{\dagger} \mathrm{z}$ and $(\mathrm{z}+\ell)$ are wetted soil depths after irrigation and redistribution, respectively, $\mathrm{t}_{\mathrm{i}}$ is adjusted operating duration of emitter, and I is irrigation interval.

For a sand soil, emitters with 16 and 24 liter/h which achieved 1.59 and $2.00 \mathrm{~d}$ irrigation interval for squash, 3.00 and $3.44 \mathrm{~d}$ for corn, and 2.17 and $2.74 \mathrm{~d}$ for grape, respectively, were recommended. The decimal values of irrigation interval were revised to integral numbers as presented in Table 4; therefore, revised wetted soil depths and operating durations of emitter were found for purpose of irrigation scheduling in the three different soil types and crops. Thus, these techniques of irrigation scheduling could only prevent the deep percolation beyond crop root zone in irrigation uniformity condition. But in non-uniformity condition of irrigation, it should be utilized based on irrigation system design.

For clay soil, moisture content contours after irrigation and soil-water redistribution were drawn under recommended 4 liter/h flow rate, $3 \mathrm{~h}$ operating duration of emitter, and $0.318 \mathrm{~m}^{3} \mathrm{~m}^{-3}$ initial soil moisture content as presented in Figs. (5a) and (5b). Figure (5a) showed that volumetric soil water content just after irrigation ranged from 55 to 53\% was concentrated in the upper $7 \mathrm{~cm}$ soil depth where presented the water 
bulb point. Soil moisture content distributed from $55-47 \%$ in the upper $20 \mathrm{~cm}$ of the soil surface. It reached $32 \%$ at $40 \mathrm{~cm}$ soil depth where vertical water advance was terminated. Average moisture content of wetted soil after irrigation was recorded as $52.9 \%$ in Table 2 . Wetted soil volume after irrigation $\left(0.08 \mathrm{~m}^{3}\right)$ was left for $48 \mathrm{~h}$; then, soil moisture content was measured and contoured as shown in Fig. (5b). It seemed that water was moved from drainable pores (macro-pores) in the upper 40 $\mathrm{cm}$ of clay soil to fill water holding pores (medium and micro pores) below in the next forty centimeters. Figure $(5 b)$ showed volumetric soil moisture content was distributed from 42 to $43 \%$ and placed in the upper $50 \mathrm{~cm}$ of the soil surface. It decreased from 42 to $34 \%$ when soil depth increased from 50 to $80 \mathrm{~cm}$, respectively. Wetted area volume after soilwater redistribution was $0.2 \mathrm{~m}^{3}$ with $42.9 \%$ final soil moisture content. Wetted soil volume shape occurred under 4 liter/h trickle source shown in Fig. (5b) was used to be revised by changing operating duration of emitter to be 1.88 and 4.50, and $13.13 \mathrm{~h}$ for squash, corn, and grape, respectively. So, water losses beyond root zone could be prevented by selecting the integral interval as shown in Table 4.

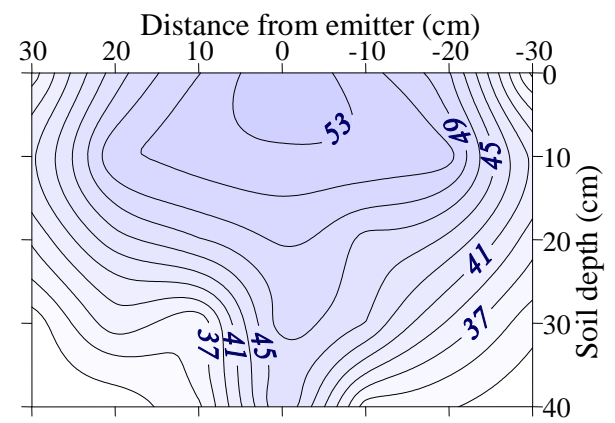

a) Volumetric soil moisture content (\%) just after irrigation.
Fig. 5. Wetted patterns under 4 liter/h flow rate and $3 \mathrm{~h}$ operating time of emitter for clay soil.

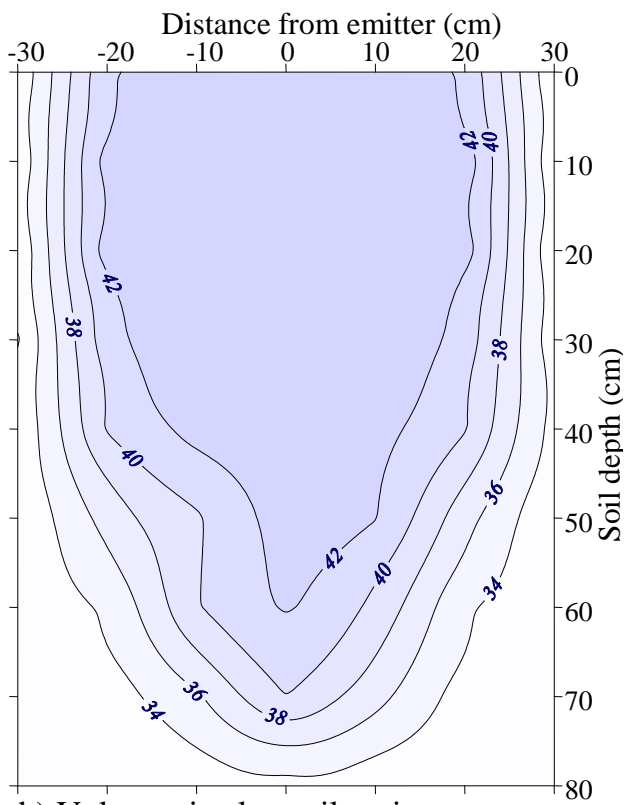

b) Volumetric clay soil moisture content (\%) after soil-water redistribution. 
For loam soil, volumetric soil moisture content under 16 liter/h flow rate, $0.75 \mathrm{~h}$ operating time of emitter, and $0.142 \mathrm{~m}^{3} \mathrm{~m}^{-3}$ initial soil moisture content was contoured just after irrigation as shown in Fig. (6a), it was after soil-water redistribution in Fig. (6b). Figure (6a) showed moisture content decreased from 34 to $30 \%$ in the upper $25 \mathrm{~cm}$ from the soil. It reached $20 \%$ at the upper $50 \mathrm{~cm}$ from soil depth where wetted soil was ended. After soil-water redistribution, figure (6b) showed moisture content was around $20 \%$ in the upper $70 \mathrm{~cm}$ from soil depth and ended to $16 \%$ at $110 \mathrm{~cm}$ soil depth. Average volumetric soil moisture was 0.327 and $0.210 \mathrm{~m}^{3} \mathrm{~m}^{-3}$ after irrigation and soil-water redistribution, respectively, for 0.124 and $0.416 \mathrm{~m}^{3}$ wetted soil volume. After soil-water redistribution, drainable water moved from the upper $50 \mathrm{~cm}$ from soil depth to fill fine holding pores (medium and micro pores) in the beneath $60 \mathrm{~cm}$ of soil depth. Wetted soil depth under 16 liter/h shown in Fig. (6b) was, respectively, revised to be as $0.58,0.90$, and $1.92 \mathrm{~m}$ to suit squash, corn, and grape irrigation scheduling as shown in Table 4.

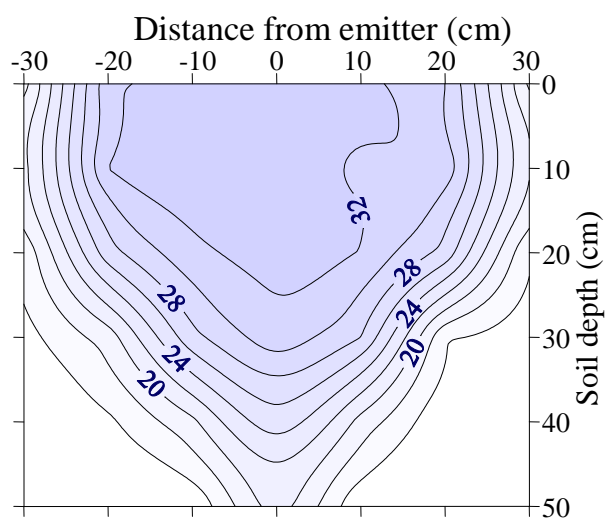

a) Volumetric soil moisture content (\%) just after irrigation.

Fig. 6. Wetted patterns under $161 / \mathrm{h}$ flow rate and $0.75 \mathrm{~h}$ operating time of emitter for loam soil.

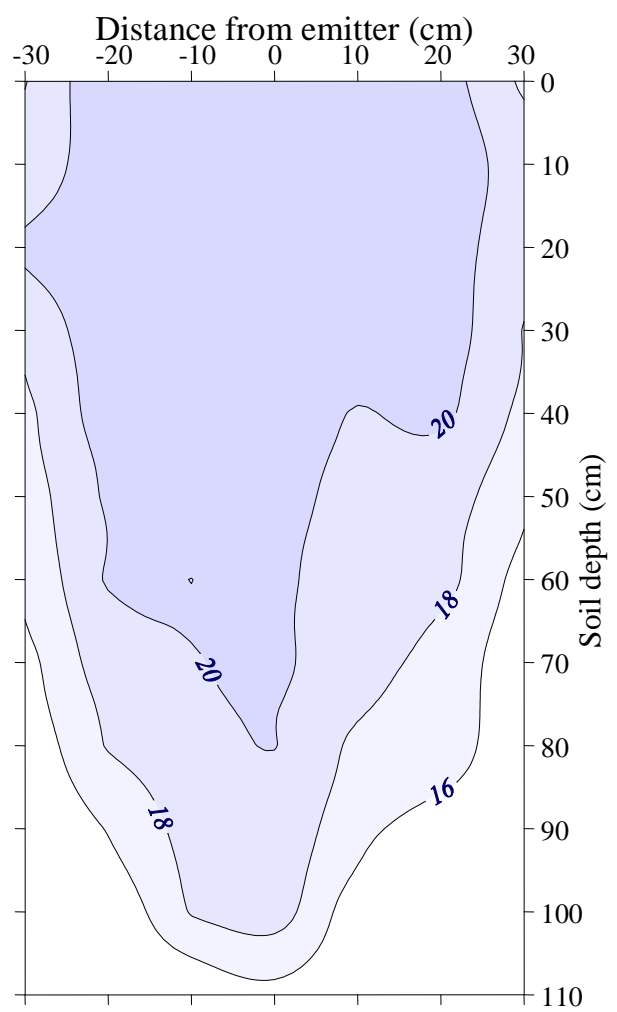

b) Volumetric soil moisture content (\%) after soil-water redistribution. 


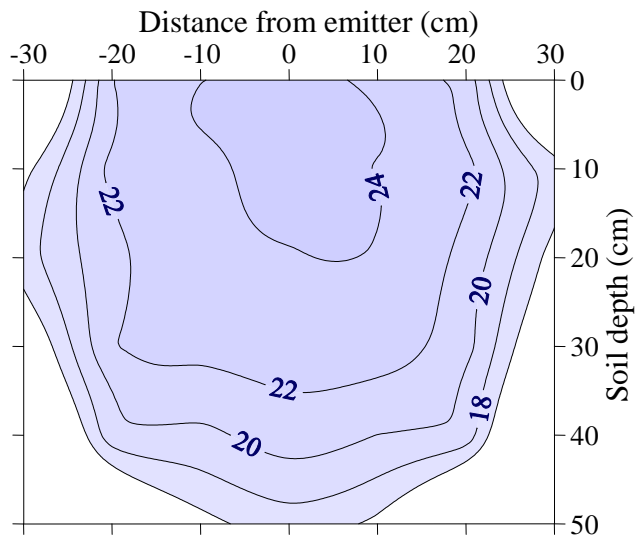

a) Volumetric soil moisture content (\%) just after irrigation.

Fig. 7. Wetted patterns under $24 \mathrm{l} / \mathrm{h}$ flow rate and $0.5 \mathrm{~h}$ operating time of emitter for sand soil.

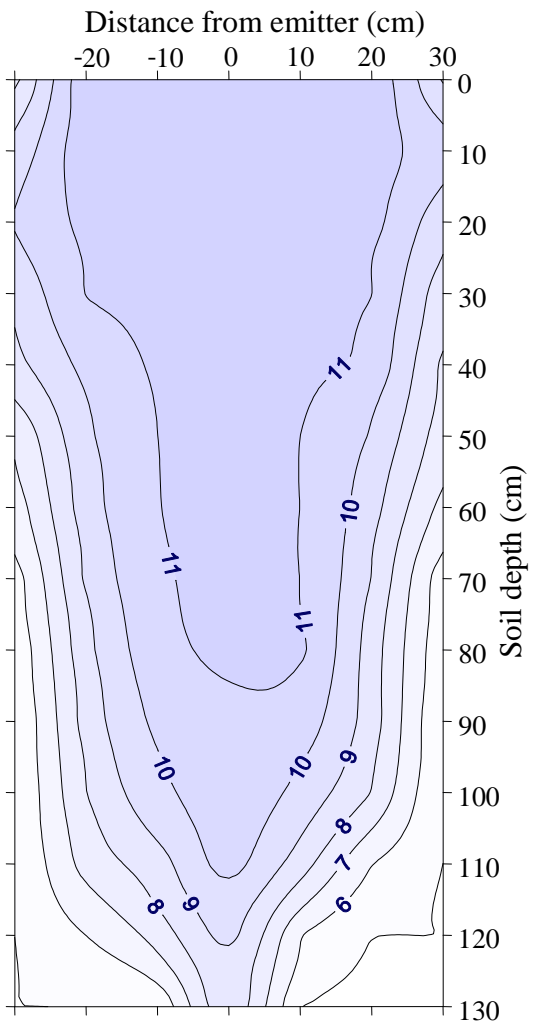

b) Volumetric soil moisture content (\%) after soil-water redistribution.

For sand soil, volumetric soil moisture content under recommended 24 liter/h flow rate, $0.5 \mathrm{~h}$ irrigation duration, and $0.05 \mathrm{~m}^{3} \mathrm{~m}^{-3}$ initial soil moisture content was contoured just after irrigation as shown in Fig. (7a), it was after soil-water redistribution in Fig. (7b). Figure (7a) showed moisture content decreased from 26 to $22 \%$ in the upper $35 \mathrm{~cm}$ of soil. It reached $16 \%$ at $50 \mathrm{~cm}$ soil depth where wetted soil was ended. After soilwater redistribution, figure $(7 \mathrm{~b})$ showed that soil moisture content was around $11 \%$ in the upper $80 \mathrm{~cm}$ soil depth and ended to $6 \%$ at $130 \mathrm{~cm}$ soil depth. Average volumetric soil moisture under 24 liter/h trickle source and $0.5 \mathrm{~h}$ operating time was 0.238 and $0.10 \mathrm{~m}^{3} \mathrm{~m}^{-3}$ after irrigation and soil-water redistribution, respectively, for 0.124 and 0.364 $\mathrm{m}^{3}$ wetted soil volume. After soil-water redistribution, drainable water moved from the upper $50 \mathrm{~cm}$ soil depth to fill holding pores (medium and micro pores) in the beneath $80 \mathrm{~cm}$ soil depth. Wetted soil depth under 24 
liter/h trickle source shown in Fig. (7b) was, respectively, revised to be as $0.51,0.98$, and $1.95 \mathrm{~m}$ to suit squash, corn, and grape irrigation scheduling.

\section{CONCLUSION}

The research aims to study the wetted soil volume as affected by soil type, flow rate, and operating duration of emitter and how to reconcile the performance of emitter to adjust the shape of wetted soil just after irrigation to make the wetted soil depth after soil-water redistribution is less than the depth of the root zone, thus preserve the water district only in root zone.

Experiments were conducted on three types of soil which were clay, loam, and sand with initial soil moisture content as 0.318, 0.142, and $0.05 \mathrm{~m}^{3} \mathrm{~m}^{-3}$, respectively. Wetted soil and moisture distribution have been identified under different emitter flow rates as 2, 4, 8, 16, and 24 liter/h with irrigation duration as $6,3,1.5,0.75,0.5 \mathrm{~h}$, respectively.

The results of this study demonstrated that trickle irrigation system performance could be improved by adjusting wetted soil volume for irrigation scheduling to account the differences in soil hydraulic properties, trickle flow rate, and irrigation interval. For a given flow rate of emitter, the wetted soil depth increased directly after irrigation as saturated hydraulic conductivity of soil increased, on the contrary wetted soil width decreased. Also given water applied amount and soil type, the wetted depth of soil increased, but width decreased as flow rate of emitter decreased. The study showed that the depth of wetted soil after soil-water redistribution increased almost double the depth just after irrigation or less more, but wetted soil width was not increased significantly. A mathematical equation was found to predict wetted depth after soil-water redistribution. Average soil moisture content of the final size of the wetted soil just after irrigation increased from 0.516 to $0.594 \mathrm{~m}^{3} \mathrm{~m}^{-3}$ in clay soil, 0.294 to $0.338 \mathrm{~m}^{3} \mathrm{~m}^{-3}$ in loam, and 0.195 to $0.234 \mathrm{~m}^{3} \mathrm{~m}^{-3}$ in sand, respectively, as flow rate of emitter increased from 2 to 24 liter/h. But, results proved that the final moisture content after soil-water redistribution was around the point of field capacity.

Comparison between calculated and measured values achieved high correlation $\left(r^{2}=0.96\right)$ with less error of estimate. Field results were 
incorporated to schedule squash, corn, and grape crops on basis of the recommended of root zone depths as $0.6,1.0$, and $2.0 \mathrm{~m}$, respectively. For a given projected crop area, peak daily crop water use was determined as 1.5, 0.9, and 30 liter/day for each squash plant, corn plant, and grape tree, respectively. Root zone depth was considered as wetted soil depth after soil-water redistribution $(z+\ell)$. Therefore, by using the characteristics of each soil and trickle system design for each crop with its daily water use, irrigation duration (t) and interval (I) on necessary to prevent leakage of water beyond the root zone were found. To integer irrigation interval to days, operating duration of emitter ( $t$ ) had been modified; therefore, depth of wetted soil just after irrigation and after soil-water redistribution were found to ensure that no increase more than the root zone. In full vegetative stage, optimal flow rate of 4 liter/h for clay soils which achieved irrigation interval as 5, 10, and 7 day, respectively, for squash, corn, and grape, 8 liter/h for loam which had 2, 3 , and 2 day irrigation interval, respectively, and 16 liter/h for sand which had 1, 3, and 2 day, respectively, as shown in Table 4.

\section{REFERENCES}

Amer, K.H., S.A. Medan, and J.L. Hatfield (2009). Effect of deficit irrigation and fertilization on cucunber. Agron. J. 101(6): 15561564.

Amer, K.H. (2010). Corn crop response under managing different irrigation and salinity levels. Agr. Water Manage., (97): 15531663.

Amir, I. and J. Dag (1993). Lateral and longitudinal wetting patterns of very low energy moving emitters. Irrig. Sci. 13: 183-187.

Ben-Asher, J., D.O. Lomen, and A.W. Warrick (1978). Linear and nonlinear models of infiltration from a point source. Soil Sci. Soc. Am. J. 42, 3-6.

Ben-Asher, J. and C.J. Phene (1993). Analysis of surface and subsurface drip irrigation using a numerical model. In: Subsurface Drip Irrigation-Theory, Practices and Application, California State University, Fresno, CA, pp. 185-202. CATI Pub. No. 92 1001. 
Bjerkholt, J.T., and E. Myhr (1996). Potential evapotranspiration from some agriculture crops. Proceedings of ASAE Conf. Nov. 3-6 in San Antonio, Texas: 317-322.

Brandt, A., E. Bresler, N. Diner, J. Ben-Asher, J. Heller, and D. Goldberg (1971). Infiltration from a trickle source. 1. Mathematical models. Soil Sci. Soc. Am. Proc. 35 (5), 675-682.

Bresler, E. (1978). Analsis of trckle irrigation wih application desin problems. Irri. Sci. 1: 3-13.

Elmaloglou, S. and N. Malamos (2006). A methodology for determining the surface and vertical components of the wetting front under a surface point source, with root water-uptake and evaporation. J. Irrig. Drain. 55 (1), 99-111.

Elmaloglou, S. and E. Diamantopoulos (2007). Wetting front advance patterns and water losses by deep percolation under the root zone as influenced by pulsed drip irrigation. Agric. water manage. 90, 160-163.

Fernandez-Galvez, J. and L.P. Simmonds (2006). Monitoring and modelling the three-dimensional flow of water under drip irrigation. Agric. water manage. 83: 197-208.

Howell, T.A., A.D. Schneider, and S.R. Evett (1997). Subsurface and surface microirrigation of corn -Southern High Plains. Trans. of the ASAE, Vol. 4(3): 635-641.

Keller, J. and R.D. Bliesner (1990). Sprinkler and trickle irrigation. Avi. Book, New York.

Schwartzman, M., and B. Zur (1986) Emitter spacing and geometry of wetted soil volume. J Irrig Drainage Engr ASCE 112:242-253.

Singh, D.K., T.B.S. Rajput, D.K. Singh, H.S. Sikarwar, R.N. Sahoo, and T. Ahmad (2006). Simulation of soil wetting pattern with subsurface drip irrigation from line source. (8 3): 130 - 134 .

Wu, J., R.Zhanh, and S. Gui (1999). Modeling soil water movement with water uptake by roots. Plant Soil 215, 7-17.

Zur, B. (1996). Wetted soil volume as a design objective in trickle irrigation. Irri. Sci. 16: 101-15. 


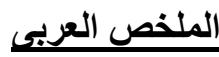 \\ تعديل حجم التربة المبتل تعت مصدر النقاط لغرض جدولة الري}

\section{"كمال حسنى عامر' أمال الثرقاوى' أحمد صلاح حسن”}

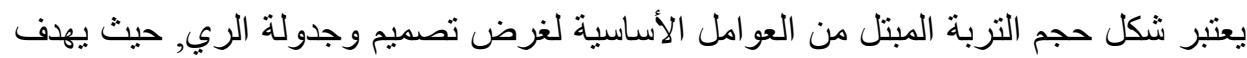
البحث إلى در اسة تأثر شكل حجم التربة المبتل بتغير نوع التربة وتصرف التهن النقاط ومدة تشغيله وكيفية تو افق أداء النقاط لنوع التربة وتحديد مدة تشغيله لضبط شكل حجم التربة المبتل بحيث لا لانئل يزيد العمق المبتل بعد إعادة توزيع مياه التربة عن عمق منطقة الجذور, بالتالي تحفظ المياه فقط

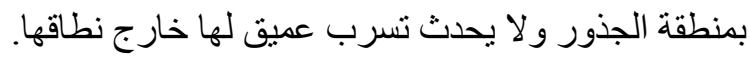
أقيمت التجربة بمزر عة كلية الزراعة - جامعة المنوفية على ثلاث أنواع من التربة هي طينية

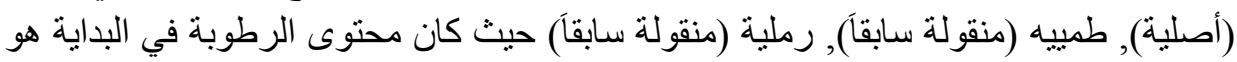

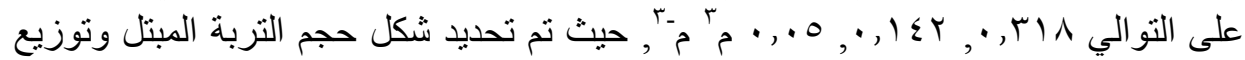

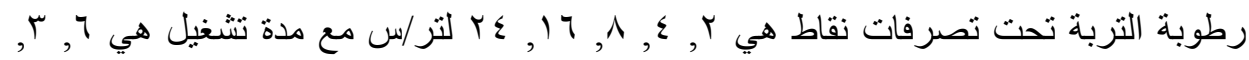
0

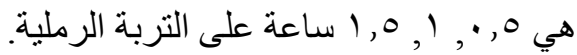
أوضحت النتائج أن بثبات تصرف النقاعة النقاط ازداد عمق التربة المبتل بعد الري مباشرة مع تز ايد معامل التوصيل الهيدروليكي للتربة, على العكس تناقص عرض الابتلال, أيضاً بثبات حجم كمية الرية

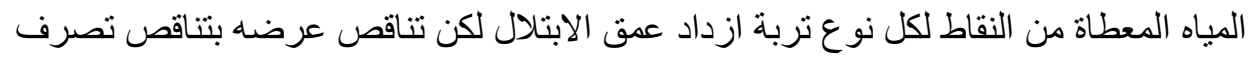

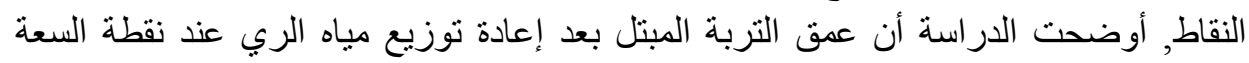
الحقلية لكل تربة تز ايد تقريباً إلى ضعف العمق بعد الري مباشرة وتم استتاج معادلة رياضية

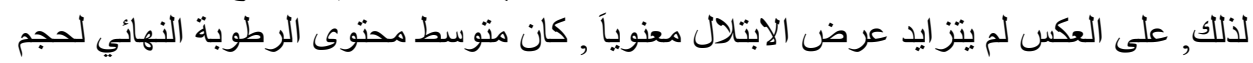

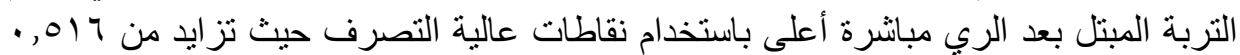

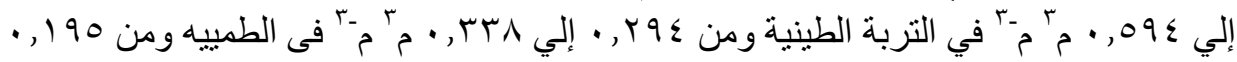

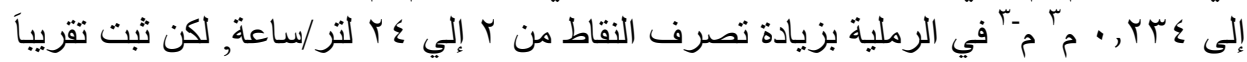

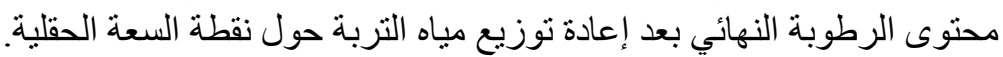

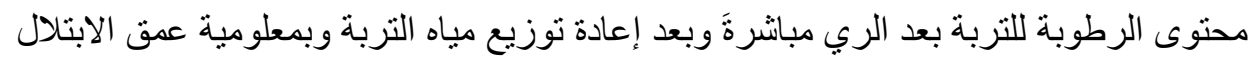

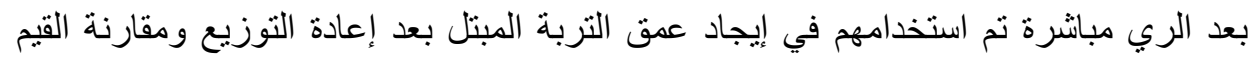

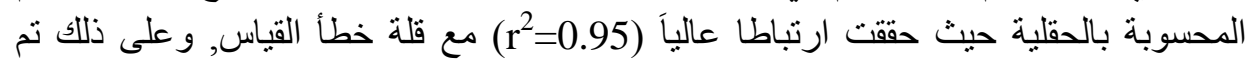

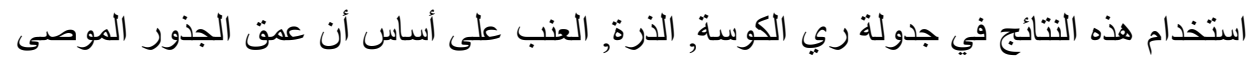

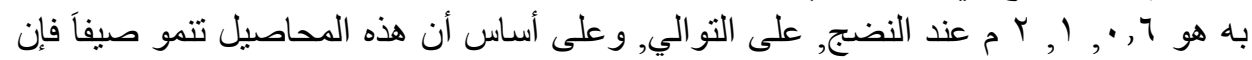

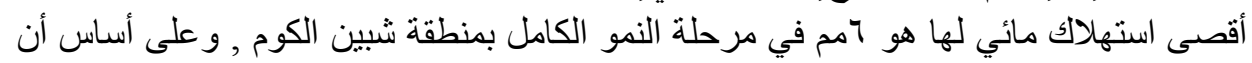

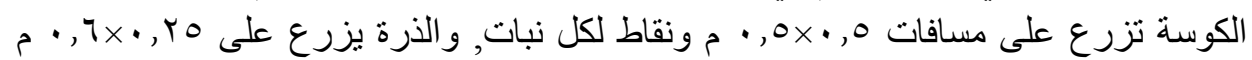

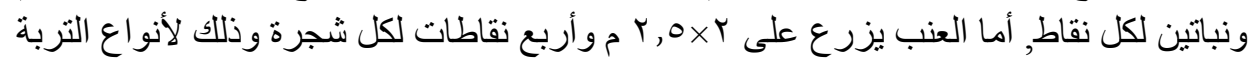

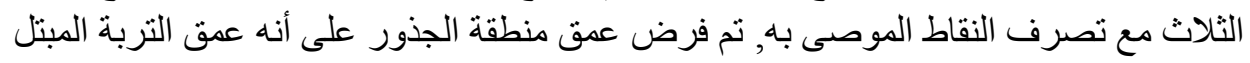

* ـ قسم الهندسة الزر اعية- جامعة المنوفية. ـ معهد البحوث للهندسة الزر اعية . 


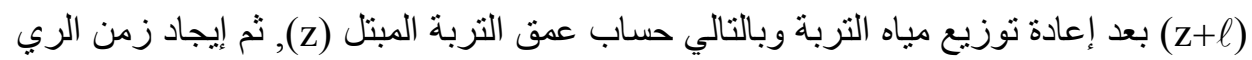

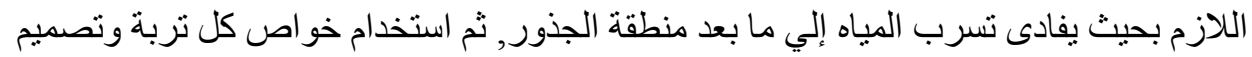

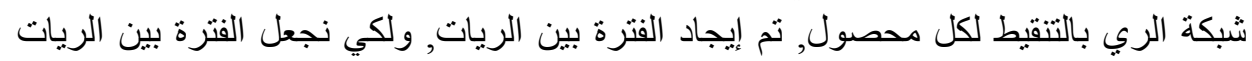

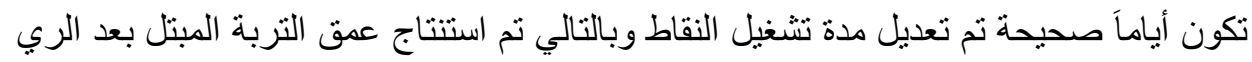

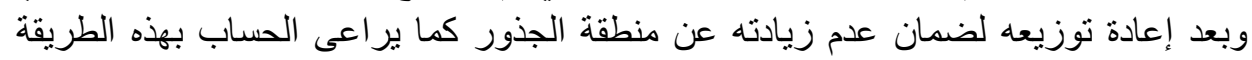

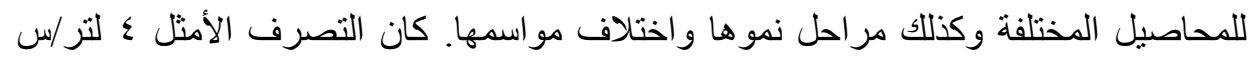

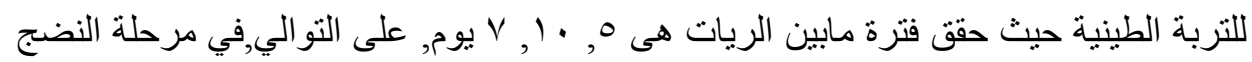

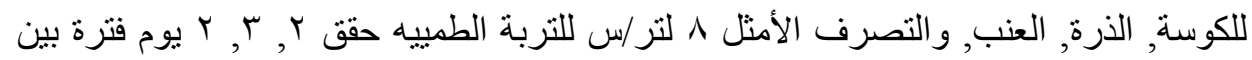

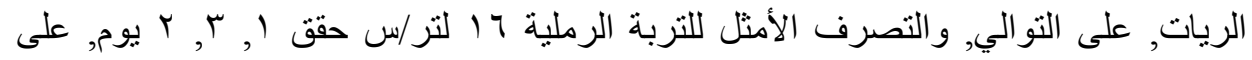
التوالي. 